\title{
ESA avoids split over space station plans ...
}

Toulouse. France and Germany last week pulled Europe's joint space programmes back from the brink of collapse in a flurry of late-night negotiations that led to agreement on Europe's participation in the international space station, and the continued development of the new Ariane-5 launcher.

The negotiations marked the nail-biting climax to a meeting of the ministers of the member states of the European Space Agency (ESA) in Toulouse, France. "Europe is back in orbit," declared a beaming Ivan Illieff, Belgium's science minister and the chairman of the three-day meeting, as he announced that consensus had been reached on all the crucial decisions that it had faced.

At Illieff's side, looking grey-faced from lack of sleep, Jean-Marie Luton, the director general of ESA, smiled nervously. "The money didn't exist, but it came," he sighed with relief, referring to the end of months of deadlock among the member states over funding of the agency's proposals.

Failure to break this deadlock would probably have led to the disintegration of ESA, claimed François Fillon, the French minister responsible for space, with Germany withdrawing in order to participate on its own alongside the station's other international partners, the United States, Russia, Canada and Japan. "It could have been handkerchief time tonight," he remarked.

But agreement has not been without its price. Both France and Germany have significantly increased their commitments to the costs of the programmes approved at the meeting. At the same time, under the agreements reached at the meeting, ESA itself will have to reduce its annual running costs of ECU170 million (US $\$ 225$ million) by 12 per cent over the next five years, and reduce its 3,500 staff by 500 .

The meeting agreed to spend ECU2.8 billion on Europe's contribution to the space station between 1996 and 2004. This will include development of the Columbus Orbital Facility (COF), to be built by Germany and Italy, an Automated Transfer Vehicle, built by France, to ferry freight and fuel to the station.

The meeting also agreed that Europe's contribution to the running costs of the station should be made in kind, and not exceed the equivalent of one Ariane- 5 flight to the station every 20 months, relieving fears among the member states that the running costs of the station might erode ESA's budget. Although this proposal will need to be approved by the other international partners, Daniel Goldin, administrator of the US National Aeronautics and Space Administration, told Luton this month that it would be acceptable.

Agreement on the financing of Europe's space station contribution was primarily the

result of France and Germany - already ESA's largest paymasters - agreeing to support each other's pet projects.

Germany's main interest is in the space station, and France, which had previously agreed to withdraw a proposal to substitute a French built crew rescue vehicle (CRV) for the planned COF space laboratory (see Nature 377,$191 ; 1995$ ), agreed to increase its funding for the German-led station programme from 16 to 27 per cent. Germany will pay 41 per cent of the costs of the programme.

At the same time, recognizing France's goal of maintaining the autonomous access of Europe to space through the Ariane launcher programme, Germany has agreed to increase its contribution to the French-led programme to further develop the Ariane-5 launcher from 7 to 17.7 per cent. The meeting agreed to spend ECU1,721.4 million on this programme between 1996 and 2003 , with France meeting almost half the costs. In a further gesture towards France, the meeting also agreed that ESA will spend

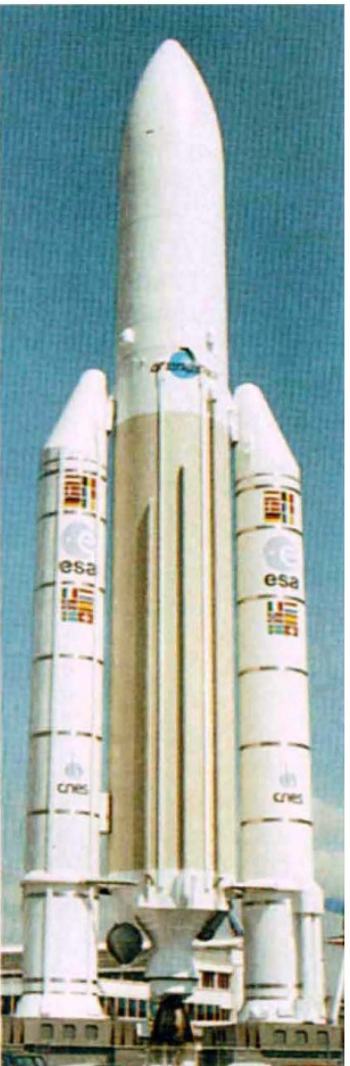

Going up: Arlane V will help to pay space station bill.

up its contribution, after France and Germany had promised that Italian industry would be awarded an extra ECU50 million in contracts, and ESA agreed to make ECU50 million of economies in the programme.

As a result, Italy will now contribute 19 per cent of the costs of ESA's contribution to the station, and 6 per cent of the costs of the Ariane development programme. The United Kingdom, which has never participated in the Ariane programme, also indicated that it would contribute 2 per cent to the launcher programme.

There will, however, be a heavy price to pay by France and Germany - as well as ESA itself - for the space station decision. The French space agency, CNES, for example, will have to cut its budget by 5 per cent to meet France's obligations.

Jacques Chirac, the French president, applauded the agreements reached. But Lionel Jospin, the leader of the opposition socialist party, criticized the level of France's increased contribution to the station programme, warning that it could damage national programmes.

But the major political outcome of the meeting seems to be the firm re-establishment of the ECU50 million on further technical studies of its CRV project.

Despite these concessions, negotiations almost broke down when Italy repeated its previous refusal to pay more than ECU100 million of the ECU300 million it had originally promised to ESA's planned contribution to the station over the period 1996-2000. Eventually, however, Italy agreed to borrow ECU150 million to make Franco-German axis as the central pillar of Europe's space programmes. Papering over the tensions of the past few months, when Germany and France were backing their rival versions of Europe's contributions to the space station, Fillon said that a critical factor had been a meeting of minds between the two countries, a sentiment echoed by Jürgen Rüttgers, his German counterpart.

Declan Butler

\section{... but holds back on space science}

Toulouse. The science programmes of the European Space Agency (ESA), considered by many as 'the jewel in ESA's crown', have fallen victim to twin pressures of a general squeeze on the space budgets of some of its member states due to their commitments to the space station (see above) and pressure from some states to shift the balance of spending back to domestic and bilateral programmes.

In the run-up to last week's ESA space ministers meeting in Toulouse, ESA had been insisting that the budget for the various programmes in its flagship Horizon 2000 science programme should be increased at the rate of inflation over the next five years. But the United Kingdom had opposed this increase, arguing that ESA could cut 25 per cent of the costs of its science missions over this time period, while Germany proposed that the budget remain level.

Under a French-brokered deal agreed at the meeting, the annual budget of the science programme will be kept constant at ECU347 million (US\$457 million) from 1996 to 1998 - roughly in line with German demands - and will be indexed only for any inflation over 3 per cent. The meeting agreed to reconsider in 1998 whether a constant budget should be maintained up to the end of the decade.

Roger Bonnet, head of ESA's science 